$$
\begin{array}{r}
\text { Г. Л. Сербин, } \\
\text { аспірант } \\
\text { (Житомирський державний університет імені Івана Франка) } \\
\text { serbinbo@ukr. net } \\
\text { ORCID: } 0000-0003-0780-0580
\end{array}
$$

\title{
ПЕДАГОГІЧНІ УМОВИ ФОРМУВАННЯ МАТЕМАТИЧНОЇ КОМПЕТЕНТНОСТІ У СТУДЕНТІВ ТЕХНІЧНИХ КОЛЕДЖІВ У ПРОЦЕСІ ФАХОВОЇ ПІДГОТОВКИ
}

\author{
У статті розглядається проблема формування математичної компетентності студентів технічних \\ коледжів; обгрунтовано та проаналізовано педагогічні умови, які впливають на формування \\ математичної компетентності студентів технічних коледжів; визначено основні наукові підходи, які \\ визначають методи, умови, фактори і принципи формування математичної компетентності у \\ студентів технічних коледжів у процесі фахової підготовки; охарактеризовано загальні вимоги до \\ фахової підготовки студентів технічних коледжів.
}

Ключові слова: математична компетентність, формування математичної компетентності, педагогічні умови, процес формування математичної компетентності, студенти технічних коледжів.

Постановка проблеми у загальному вигляді та іï зв'язок із важливими науковими i практичними завданнями. Сьогодні освіта, яку здобувають у коледжах, технікумах, училищах набуває особливого значення. Тому викликом суспільства $\epsilon$ внесення змін до системи навчання, яке здійснюють коледжі та інші вищі навчальні заклади I-II рівнів акредитації, з метою забезпечення ії відповідності світовим стандартам. Модернізація виробництва, упровадження науково-технічних досягнень і новітніх технологій, використання сучасної техніки на ринку праці різко зумовлює попит на спеціалістів високої кваліфікації, які мають технічну освіту, здатні приймати рішення, самостійно долати виробничі проблеми. У зв'язку з цим важливого значення набуває підготовка спеціаліста технічного коледжу 3 орієнтацією його діяльності на забезпечення потреб галузей економіки та ринку праці, здатного до творчої та практичної діяльності, яка може реалізуватися під час вивчення математичних дисциплін. Це, в свою чергу, вимагає оновлення основних напрямів та завдань реформування коледжів, зокрема, орієнтація на вчасне оновлення системи підготовки молодших спеціалістів в умовах інтеграції освіти України; упровадження освітніх програм та інноваційних технологій навчання, що сприятимуть удосконаленню якості професійної підготовки фахівців для забезпечення їх конкурентоспроможності на ринку праці, орієнтації до вимог інформаційно-технологічного суспільства та змін, що відбуваються в соціально-економічній і духовній сферах.

Аналіз основних досліджень і публікацій із зазначеної проблеми. Шлях формування математичної компетентності досить складний та різносторонній, оскільки об'єднує та гармонізує процеси викладання та учіння, визначає діяльність викладача і студента, а тому вимагає визначити і теоретично обгрунтувати саме такі педагогічні умови, застосування яких буде найоптимальнішим і сприятиме ефективності процесу формування математичної компетентності студентів технічних коледжів. Варто відмітити, що науковці неодноразово звертаються до проблеми формування математичної компетентності у студентів різних спеціальностей, $є$ багато наукових досліджень, зокрема: О.В.Аверіної, М. С. Амосова, І. В. Бачевської, Д. О. Булавіна, І. М. Главатського, М. С. Головань, О. В. Комісаренко, М. М. Міншіна, Е. М. Токарчук, В. Г. Плахової, Я. Г. Стельмах, Т. І. Федотової та інших. У цих дослідженнях доведено, що кожна професійна діяльність має свою специфіку, однак саме математичні дисципліни дозволяють краще врахувати найрізноманітніші профілі професійної освіти. Проте було виявлено, що немає єдиного погляду на тлумачення поняття математичної компетентності, неповністю визначено склад структурних компонентів математичної компетентності, методи, форми і фактори, що слугують формуванню математичної компетентності фахівців. До того ж, серед науковців-дослідників немає і єдиного погляду у визначенні і встановленні пріоритетності педагогічних умов формування математичної компетентності. Що і дозволило нам довести актуальність формулювання мети і завдань статті, а тому метою статті $\epsilon$ визначення та теоретичне обгрунтування педагогічних умов формування математичної компетентності у студентів технічних спеціальностей у процесі фахової підготовки.

Виклад основного матеріалу 3 обгрунтуванням отриманих наукових результатів. В основі становлення системи освіти у ВНЗ І-ІІ рівнів акредитації лежить ідея розвитку та формування особистості студента, що здійснюється завдяки реалізації особистісно орієнтованого та індивідуальнотворчого підходів, які забезпечують особистісний рівень оволодіння спеціальністю, формування творчої індивідуальності випускника. При реалізації цієї дидактичної умови кожен студент має можливість проявити свої здібності, нахили, уподобання. Знання та врахування індивідуальних особливостей забезпечують більш успішний розвиток особистісних якостей майбутнього спеціаліста. Важливого значення набуває також належність людей до різноманітних, неповторних соціальних утворень без яких 
розвиток особистості взагалі неможливий - це сім’ї, общин, соціальних груп, націй, народів, держав тощо. Тут важливою умовою виступає обгрунтування розвитку особистості в умовах трансформації суспільного устрою, тому при вивченні підвищення рівня якості підготовки слід враховувати психологічні риси студентів та їх оточення, в якому вони знаходились і перебувають на даний момент. Ще однією умовою є процес засвоєння та особистісне усвідомлення кожним студентом теоретичних положень професійної діяльності, а тому етапи засвоєння знань розглядаються разом з етапами засвоєння діяльності. Знання відразу включаються в структуру дій, їх якість визначається адекватністю діяльності, що застосовується для їх засвоєння. Тому оптимальним шляхом забезпечення якості фундаментальної підготовки є включення студента в активну діяльність та реальний аналіз різних видів практичних i розумових дій, що входять до їх складу, та попереднє навчання кожної з цих дій.

Наступну педагогічну умову формування математичної компетентності визначає принцип психологокогнітивної теорії, відповідно до якого студент розглядається як активний організм, який збирає інформацію з метою іï накопичення та використання (збирання інформації в процесі навчання). Предметом такої діяльності $€$ пізнавальні процеси, від найпростіших до найскладніших, а індивідуальність є системою пізнавальних структур. Аналіз теорії поетапного формування мислення дозволив визначити, що діяльність є умовою для формування пізнання. Для повноцінного формування будь-якого нового знання і вміння треба дотримуватися таких етапів: створення мотивації; роз'яснення або виділення схеми орієнтовної дії; формування дії в матеріальній або матеріалізованій формі; мовлення без опори на матеріально-матеріалізовані засоби; формування дій у внутрішній мові; перехід дії у внутрішню мову, а внутрішньої мови - у думку [1].

Необхідною умовою посилення ефективності формування математичної компетентності у процесі професійної підготовки студентів набуває теорія стилів навчання. Так, рівень якості підготовки залежить від відповідності умов навчання переважному стилю навчання. Було виділено основні сфери, в яких виявляються стилі навчання та які містять у собі потреби й переваги особистості щодо освітнього середовища, їх мотивацію, соціологічний аспект навчання й фізичні потреби в особливій організації навчання. Сполучення стилів навчання за всіма сферами утворюють профіль кожного, хто навчається. Отже, під час організації навчання педагог враховує індивідуальний профіль особистості й забезпечує умови, що максимально сприяють забезпеченню якості навчання [2].

Важливою умовою у формуванні математичної компетентності $\epsilon$ технологічне забезпечення навчального процесу. Його реалізація здійснюється у вигляді застосування в навчальному процесі сучасних технологій навчання, які формують необхідне інформаційне середовище, що сприяє активній педагогічній взаємодії викладача і студента. Відповідно до мети навчання поставленими завданнями і використаними методами визначається структура дидактичного комплексу, який виступає як ключовий елемент і служить основою технології навчання. У навчальному процесі необхідно враховувати параметри, що забезпечують якісну підготовку фахівців: логічну структуру, дозування матеріалу i контрольних завдань, опис дидактичного процесу у вигляді поетапної послідовності дій педагога, методи навчання тощо [3: 173].

У ході дослідження було встановлено, важливою педагогічною умовою також $є$ реалізація акмеологічного підходу, оскільки акмеологія освіти досліджує умови досягнення високої якості освітніх систем і розвитку суб'єктів освітнього процесу - викладачів і студентів.

Оскільки сучасна освіта орієнтується на розвиток ключових компетентностей, то зміст реалізації компетентнісного підходу полягає в зміщенні акценту з накопичування нормативно визначених знань, умінь і навичок до формування й розвитку у студентів здатності практично діяти, застосовувати індивідуальні техніки й досвід успішних дій у ситуаціях професійної діяльності та соціальної практики. Перспективність компетентнісного підходу полягає в тому, що він передбачає високу готовність випускника закладу освіти до успішної діяльності в різних сферах. Аналіз літературних джерел підтвердив, що в комплексі освітніх компетенцій закладено додаткову можливість представити освітні стандарти системно, що допускає побудову чітких параметрів для перевірки якості професійної підготовки. 3 огляду на вимоги щодо рівня підготовки випускників освітні компетенції є інтегральними характеристиками якості підготовки студентів, які пов'язані з їх здатністю до цільового осмисленого застосування комплексу знань, умінь і способів діяльності стосовно визначеного міждисциплінарного кола питань.

Ефективною умовою реалізації означеного дослідження виявилася також теорія повного засвоєння знань, оскільки різні рівні підготовки, як правило, пояснюються відповідним розвитком здібностей до навчання. Доведено, що у традиційному навчальному процесі завжди фіксуються параметри умов навчання (однакові для всіх навчальний час, спосіб подачі інформації тощо), а наслідки навчання залишаються незафіксованими. Тому у професійній підготовці саме результати навчання треба зробити фіксованим параметром, в такому випадку, умови навчання будуть змінюватися, задовольняючи досягнення всіма учнями наперед заданого результату. Власне, якщо на відміну від традиційного навчання, оптимізувати умови навчального процесу (насамперед за темпами учіння), то навчальний 
матеріал буде повністю засвоєний майже всіма учнями. За таких умов навчального процесу, тобто на основі повного засвоєння, майже всі учні повинні досягти повного засвоєння матеріалу [4].

Процес модернізації освітньої діяльності в Україні зумовлює, щоб якість освіти охоплювала всі основні функції та напрями діяльності, а саме: якість викладання, підготовки й дослідження, що зумовить в свою чергу якість відповідного персоналу й програм. Поняття, пов’язані з якістю, відіграють важливу роль у визначенні характеру функціонування того чи іншого конкретного навчального закладу, оцінці його діяльності й формуванні його "інституційного іміджу" в академічному співтоваристві й суспільстві в цілому.

Сучасне суспільство має потребу у високоосвічених і мотивованих фахівцях, здатних виконувати відповідні функції в державних і приватних організаціях. Тому держава зацікавлена в забезпеченні високої якості підготовки майбутніх фахівців. А це у свою чергу вимагає зміни якості освіти, самої системи освіти, якості системи освіти. Тому важливою умовою є узгодження внутрішньої структури системи освіти і концептуальні засади ії діяльності з зовнішніми соціальними чинниками. Оскільки доведено, що якість освіти - це узагальнений показник розвитку суспільства в певному часовому вимірі, то iі слід розглядати в динаміці тих змін, що характеризують поступ держави в контексті світових тенденцій. У законодавстві України якість освіти визначено як "відповідність результатів навчання вимогам, встановленим законодавством, відповідним стандартом освіти та / або договором про надання освітніх послуг" [6]. Аналіз інших джерел дозволив зробити висновок, що якість вищої освіти - це багатовимірне поняття, яке охоплює усі сторони діяльності вищого навчального закладу: навчальні та академічні програми, навчальну і дослідницьку роботу, професорсько-викладацький склад і студентів, навчальну базу і ресурси. Крім того, якість вищої освіти є поняттям, яке характеризується численними аспектами й значною мірою залежить від контекстуальних рамок даної системи, інституціональних завдань чи умов і норм даної дисципліни [4]. Тому можна зробити висновок, що якість освіти визначає умови, які мають відношення до якості підготовки студентів, інфраструктури й навчального середовища.

Професійна підготовка для різних освітньо-кваліфікаційних рівнів визначається галузевими стандартами вищої педагогічної освіти та стандартами освіти вищого навчального закладу. Як показав аналіз психолого-педагогічної літератури, професійна підготовка в технічному вищому навчальному закладі поділяється на три головні напрями: фундаментальна, гуманітарна, професійно-практична.

На сучасному етапі розвитку системи освіти йде пошук шляхів забезпечення якості фундаментальної освіти, що дає можливість людині в подальшому самостійно працювати, навчатися та переучуватися. Саме людина знає закони природи, закони розвитку суспільства, вміє логічно міркувати, аналізувати та пов'язувати факти, приймати рішення, вивчати явища з наукової точки зору. До таких наук відносяться науки природничо-математичного циклу, вивчення яких здійснюється шляхом створення інваріантних, ідеалізованих моделей, які перевіряються на практиці спеціалістами, що проектують та реалізують їх у власній діяльності. Саме фундаментальна підготовка $\epsilon$ загальнонауковою основою формування особистості, спрямованої на відтворення інтелектуального потенціалу суспільства, його системи цінностей, традицій і забезпечення внутрішнього зв'язку часу від покоління до покоління.

У цілому вивчення дисциплін, що є складовими фундаментальної підготовки майбутніх спеціалістів на заняттях з математики, спрямоване на формування загальної математичної культури, необхідної майбутньому спеціалісту технічних дисциплін, оволодіння комплексом математичних методів та розвиток навичок застосування їх на практиці, розгортання теоретичних основ для прикладних наукових досліджень, забезпечення зв'язку з методичною підготовкою.

Так, якість фундаментальної підготовки залежить від оптимального підбору змісту, від шляхів реалізації навчальних дисциплін (технології, методичної системи тощо), від компетентності фахівців вищих навчальних закладів I-II рівнів акредитації. В процесі фундаментальної підготовки будемо спрямовувати наші зусилля на підвищення рівня математичних якостей майбутніх спеціалістів технічних коледжів. Так, під впливом математичної освіти розвиваються наступні якості: кмітливість; здогадливість; гнучкість розуму; адаптивність поведінки; помітно розвивається пам'ять, особливо спрямована на мимовільне запам'ятовування; покращуються можливості вхідного каналу логічних здібностей людини; розширюється операційний склад здібностей математиків; підвищена серйозність; незалежність міркувань; інтровертованість. Як відомо, результат засвоєння "якісних" знань виражається оцінкою успішності. Успіх навчання віддзеркалює якість навчальної діяльності як процесу, що відбувається в часі і пов'язаний із засвоєнням визначеної суми знань, умінь, навичок, комплексу громадських норм, із набуттям соціального досвіду. Успішність - це фіксований (проміжний чи кінцевий) в умовних кількісних показниках результат процесу навчання, який відображає успіх студента у процесі навчання. Також, встановлено, академічна успішність - це не лише міра пізнавальної діяльності, де фіксуються рівень і обсяг знань, ступінь старанності, але й відношення студентів до своєї спеціальності, ступінь відповідності інтересів і схильностей індивідів цільовій функції університету [4]. У практиці навчання може спостерігатися різне поєднання рівнів успішності з тих чи інших дисциплін або блоків дисциплін. Дана обставина відображає індивідуально-психологічні особливості окремих 
студентів, їх інтереси, направленість тощо. Для успішного навчання на заняттях з математики, предметах технічних дисциплін необхідним є досить високий рівень загального інтелектуального розвитку, зокрема сформованості процесів сприймання, уявлення, пам'яті, мислення, високої концентрації уваги, широти пізнавальних інтересів, ерудованості, володіння визначеним колом логічних операцій. Далі під впливом математичної освіти більш за все розвивається тямущість; здогадливість; гнучкість розуму; адаптивність поведінки; помітно розвивається пам'ять, яка особливо спрямована на мимовільне запам'ятовування.

Однією з важливих умов формування компетентності є психологічна готовність до обраної професії. Важливо робити прогноз на основі схильності особистості до визначеного виду діяльності (наприклад, за допомогою фахового тестування, професіограм). Випадковий вибір майбутньої професії дорого обходиться суспільству та особистості.

Для створення сприятливих умов навчання важливо визначити стресову до екзаменаційну та екзаменаційну ситуації. Психічні й фізіологічні порушення в організмі під впливом іспитів можуть набувати навіть характеру патології (наприклад, спричиняти гостру депресію та інші серйозні захворювання). Результати досліджень фізіологів і психологів свідчать, що доекзаменаційні й екзаменаційні ситуації дуже впливають на стан організму й психіки студента. Характер наук, які ми досліджуємо вимагає цю обставину не випускати з огляду, бо в іспитах 3 математичних дисциплін без точного знання фізичних чи математичних законів, теорем, формул тощо неможливо відповісти на питання білета з відповідних дисциплін навіть при загальній ерудиції й широкому кругозорі. Врахування таких умов дозволить знизити психологічну напруженість.

Сучасне, оновлене інформаційно-методичне забезпечення $\epsilon$ однією 3 важливих умов процесу ефективного формування компетентності спеціаліста різних сфер. Обов'язковим є використання в навчальному процесі прикладних педагогічних програмних продуктів, баз даних, методичних засобів i матеріалів, психолого-педагогічної літератури щодо доступного вивчення фундаментальних дисциплін. Чим більше в студента можливостей отримати нову й достовірну інформацію, тим більші його потенційні можливості щодо підвищення якості підготовки.

Отже, виходячи з загальної мети та завдань нашої статті, педагогічними умовами забезпечення якості професійної підготовки майбутніх технарів та заняттях 3 математики будемо називати ті основні внутрішні та зовнішні причини, які зумовлюють підвищення рівня якості фундаментальної підготовки майбутніх спеціалістів і піддаються корекції в межах навчального процесу.

Таким чином було виявлено, що забезпечення формування математичної компетентності у студентів технічних коледжів у процесі фахової підготовки зумовлено рядом педагогічних умов: реалізацією особистісно орієнтованого та індивідуально-творчого підходів; мотивацією, організацією навчального процесу відповідно до інтересів кожного члена колективу; самооцінкою ціннісного ставлення до професіоналізму; психологічною готовністю до обраної професії; матеріально-технічним та інформаційно-методичним забезпеченням закладу. Врахування зазначених груп факторів забезпечить можливість підвищувати рівень навчальних досягнень 3 основ спеціальності майбутніх спеціалістів, запобігати академічній неуспішності, допоможе молодим викладачам при виборі стратегії й тактики своєї діяльності.

Висновки та перспективи подальшого дослідження проблеми. Водночас, вимагає дослідження проблема розробки технологій підготовки студентів технічних коледжів у процесі фахової підготовки, що сформують високий рівень розвитку у студентів професійного мислення, здатності розв'язувати завдання, які максимально наближені до професійних.

\section{СПИСОК ВИКОРИСТАНИХ ДЖЕРЕЛ ТА ЛІТЕРАТУРИ}

1. Слєпкань 3. І. Психолого-педагогічні та методологічні основи розвивального навчання математики / 3. І. Слєпкань. - Тернопіль : Підручники і посібники, 2004. - 240 с.

2. Нєдялкова К. В. Педагогічні умови інтелектуального розвитку майбутніх учителів математики у процесі фахової підготовки : дис. ... канд. пед. наук : 13.00.04 / Нєдялкова Катерина Василівна. - О., 2003. - 218 с.

3. Вища освіта України і Болонський процес : [навчальний посібник] / За редакцією В. Г. Кременя. - Тернопіль : Навчальна книга - Богдан, 2004. - 384 с.

4. Чемерис О.А. Педагогічні умови інтелектуального розвитку майбутніх учителів математики у процесі фахової підготовки : дис. ... канд. пед. наук : 13.00.04 / Чемерис Ольга Анатоліївна. - О., 2003. - 218 с.

5. Рибалка В. В. Методологічні питання наукової психології (Досвід особистісно центрованої систематизації категоріально-поняттєвого апарату) : [навчально-методичний посібник]. - К. : Ніка-центр, 2003. - 204 с.

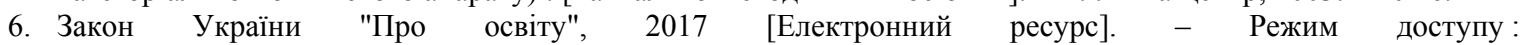
http://zakon3.rada.gov.ua/laws/show/2145-19.

\section{REFERENCES (TRANSLATED \& TRANSLITERATED)}

1. Sliepkan Z. I. Psykholoho-pedahohichni ta metodolohichni osnovy rozvyval'noho navchannia matematyky [Psychological and Pedagogical Methodological Foundation of Mathematics Developmental Teaching]/ Z. I. Sliepkan. - Ternopil' : Pidruchnyky i posibnyky, 2004. - 240 s. 
2. Niedialkova K. V. Pedahohichni umovy intelektual'noho rozvytku maibutnikh uchyteliv matematyky u protsesi fakhovoi pidhotovky [Pedagogical Conditions of Quality Provision of Fundamental Training of the Future Teachers of Mathematics in the Process of Professional Training] : dys. ... kand. ped. nauk: 13.00.04/ Niedialkova Kateryna Vasylivna. - O., 2003. - 218 s.

3. Vyshcha osvita Ukrainy i Bolons'kyi protses [Higher Education in Ukraine and Bologna Process] : [navchal'nyi posibnyk] / Za redaktsiieiu V. H. Kremenia. - Ternopil' : Navchal'na knyha - Bohdan, 2004. - 384 s.

4. Chemerys O. A. Pedahohichni umovy intelektual'noho rozvytku maibutnikh uchyteliv matematyky u protsesi fakhovoi pidhotovky [Pedagogical Conditions of Quality Provision of Fundamental Training of the Future Teachers of Mathematics.] : dys. ... kand. ped. nauk : 13.00.04 / Chemerys Olha Anatoliivna. - O., 2003. - 218 s.

5. Rybalka V. V. Metodolohichni pytannia naukovoi psykholohii (Dosvid osobystisno tsentrovanoi systematyzatsii katehorialno-poniattievoho aparatu) [Methodological Issues of Scientific Psychology (Experience of Personal Centered Framework of Categories and Concepts)] : [navchal'no-metodychnyi posibnyk] / V. V. Rybalka. - K. : Nika-tsentr, 2003. - $204 \mathrm{~s}$.

6. Zakon Ukrainy "Pro osvitu", 2017 [The Law of Ukraine "On Education"] [Elektronnyi resurs]. - Rezhym dostupu : http://zakon3.rada.gov.ua/laws/show/2145-19.

\section{Сербин Г. Л. Педагогические условия формирования математической компетентности студентов технических колледжей в процессе профессиональной подготовки.}

В статье рассматривается проблема формирования математической компетентности студентов технических колледжей; обосновано и проанализировано педагогические условия, влияющие на формирование математической компетентности студентов технических колледжей; определень основные научные подходы, которые определяют методы, условия, факторы и принципы формирования математической компетентности студентов технических колледжей в прочессе профессиональной подготовки; охарактеризовань общие требования к профессиональной подготовке студентов технических колледжей.

Ключевые слова: математическая компетентность, формирование математической компетентности, педагогические условия, процесс формирования математической компетентности, студенты технических колледжей.

\section{Serbyn G. L. Pedagogical Conditions for Forming Students of Technical Colleges Mathematical Competence} in the Process of Professional Training.

Analysis and study of psycho-pedagogical and special literature allowed outlining the main concepts of the problem, which allowed differentiating the main features of the mathematical competence formation, the main pedagogical approaches that improve the process of training specialists in technical specialties. Thus, the modernization of production, the introduction of scientific and technological advances and the latest technology, the use of state-of-the-art equipment in the labor market sharply determines the demand for highly skilled specialists.

A number of factors influence the definition of the necessary pedagogical conditions for mathematical competence formation. The best way to ensure the quality of basic training is to include the student in active work and a realistic analysis of various types of practical and mental activities. Technological support of the educational process determines and promotes active pedagogical interaction of the teacher and the student. It is important to remember that the quality of education is a generalized indicator of the development of society in a

certain time dimension. She also pays attention to all aspects of higher education: academic and academic programs, academic and research work, faculty and students, training facilities and resources. The quality of education determines the conditions that are relevant to the quality of student training, infrastructure, and learning environment.

One of the important conditions for the formation of competence is psychological readiness for the chosen profession. It is important to make a forecast based on the person's predisposition to a particular type of activity.

Key words: mathematical competence, formation of mathematical competence, pedagogical conditions, process of formation of mathematical competence, students of technical colleges. 